\title{
RAKAS KENIA
}

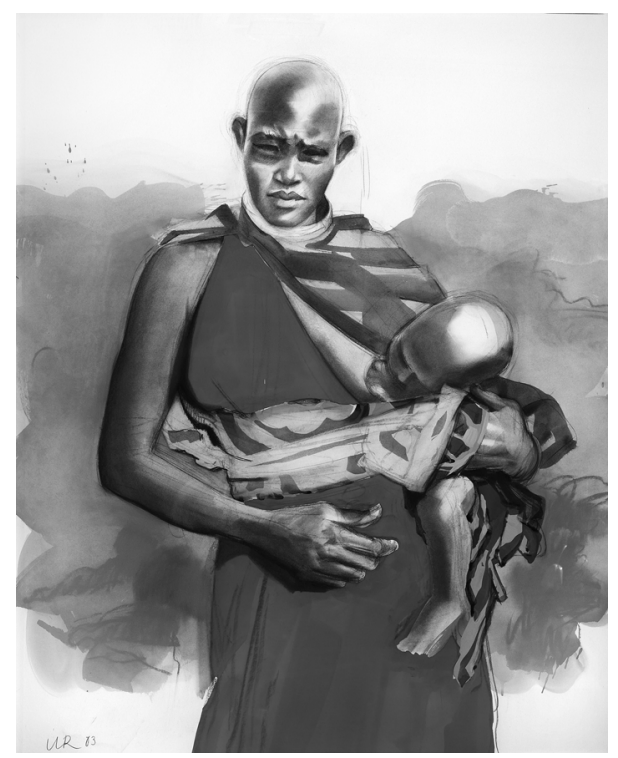

Ulla Rantanen: Äiti ja poika, 2003, guassi paperille, 153 x $125 \mathrm{~cm}$. Valokuva: Jouko Järvinen.

Kymmenen viime vuoden aikana Keniasta on tullut taiteilija Ulla Rantasen (s. 1938) toinen kotimaa, jossa hän asuu ja työskentelee säännöllisesti pitkähköjä jaksoja. Talonkin työtiloineen taiteilija on rakennuttanut itselleen paikallisesta kivimateriaalista lähelle Nairobia. Maisema on lähes puutonta kumpuilevaa maastoa kuin Lapissa. Karen Blixenin asuinalue näkyy Rantasen kodin tornista.

Itä-Afrikka mullisti Rantasen tietoisuuden väreillään, valollaan ja elämänotteensa voimalla. Hän, kuten samoilla seuduilla jo 1900-luvun alussa työskennellyt taidemaalari Akseli Gallen-Kallela, vaikuttui ja vakuuttui Afrikan vastustamattomasta kauneudesta ja suoruudesta. Rantanen varoittaa kliseistä ja sanojen latteudesta, mutta elämystensä voimaa hän ei voi vähätellä. Afrikka on antanut hänelle impulsseja, jotka ovat laajentaneet hänen taideilmaisuaan ja johtaneet uuteen synteesiin.

Taiteilijana Rantanen on ennen muuta piirtäjä, joka muistetaan hyvin hänen 1960- ja 1970lukujen pop-taiteestaan ja uusrealismistaan. Figuratiivisuus ja yhteiskunnallisuus vaihtuivat hänen 1980-luvun töissään sisäistä ja ulkoista luontoa kuulostelevaksi puoliabstraktioksi. Rantasen uusimmissa maalauksissa kaikki nämä pyrkimykset risteilevät afrikkalaisen ihmisen, elämänmuodon ja luonnon tulkkeina. Kenialaisia paimentolaisystäviään kuvatessaan hän ei kätke ihailuaan, vaan antaa yksinkertaisiin värikkäisiin vaatteisiin puettujen jäntevien mustien ihmisten näyttää ylväytensä. Tällaista suoruutta Rantasen pidättyvässä ilmaisussa ei ole ennen ollut. Taiteilijan katseessa on rakkautta, kristillistä asetelmallisuutta ja asenteellisuutta, erotiikkaakin mutta ennen muuta arvostusta. Se on kaukana kolonialismista ja etnografisuudesta.

Kenialaisten ystävien lisäksi Rantasen maalausten aiheita ovat perinteinen veistoksellinen savimaja, lehtevät maisemat ja vedenottopaikat, kuten betoninen allas, johon johdetaan Kilimanjaron purojen vettä, tai lähinnä sadeveden täyttämät saviset lammikot. Primitiivisen elämänmuodon idylliä murtaa kuitenkin Muuri-maalaus, joka kertoo luokkayhteenotoista ja rotujen ja kulttuurien välisistä jännitteistä. Valkoinen ihminen on Keniassa aina viesti varallisuudesta ja varallisuuseroista. Turvallisuus ja rikollisuuden torjuminen edellyttävät valitettavasti myös eristäytymistä piikkilangan ja kivimuurin suojiin. 